\title{
Technological aspects of increasing consumer properties and biological value of cattle meat
}

\author{
Andrey Mamaev *, Vladimir Masalov, Konstantin Leshchukov, Konstantin Konovalov \\ Orel State Agrarian University named after N. V. Parakhin, Faculty of Biotechnology and Veterinary \\ Medicine, Generala Rodina, 69, Orel, Russia
}

\begin{abstract}
The importance of the study is in the development of canned beef with increased biological value. The plant complex "spirulina-flax" was used for the modernization of canned meat. A corresponding goal and objectives of research on the study of new canned meat, the development of recipes, chemical composition and in vitro digestibility were formulated. Development of new canned foods was carried out in the laboratories of N.V. Parakhin Oryol State Agrarian University and "Oryolproduct" of Mtsensk district, Oryol region. Four samples of canned beef were produced in laboratory conditions. Three of them contained different amounts of spirulina-flax complex. Canned beef "Stewed meat" per GOST 321252013 was taken as a control. Additional vegetable raw materials can increase the biological value of canned meat due to vitamins, minerals and dietary fiber, while maintaining the requirements of GOST. The added plant complex enriches the product with biologically valuable components of plant origin, with a slight increase in the energy value. Based on the data, it is possible to recommend enterprises to use the obtained composition for the production of canned food with an increased biological value. And also based on the obtained results, it is possible to develop new recipe compositions in the conditions of the enterprise.
\end{abstract}

\section{Introduction}

Improving the efficiency of food production with indicators of increased nutritional and biological value for mass consumption is one of the priorities of the Russian state policy in the field of healthy nutrition and import substitution [1]. It is possible to achieve such an effect by enriching products of public consumption with the main essential nutrients, by optimizing the ratio of animal and plant components in the recipe, ensuring the multicomponent composition of the developed food products. In addition, one of the priority areas of the food industry is the organization of industrial production of functional food for various groups of the population following the new challenges of modern science $[2,3]$. At the same time, at present, more and more attention is paid to the development of food products with an optimal ratio of their constituent components [4, 5, 6, 7, 9]. Scientific theory explains the direct dependence of the human body's metabolism on the state of the immune system, the functioning of which depends not only on the optimal ratio of

\footnotetext{
* Corresponding author: shatone@mail.ru
} 
macronutrients, but also on a large amount of micronutrients in the diet. As you know, meat and meat products are a necessary nutritional component with a complex of essential amino acids and a valuable range of mineral elements and vitamins. However, the low energy value does not allow the use of meat as a full-fledged source of energy, but it can be successfully combined with plant components in the recipes of functional products to increase their nutritional and biological value.

The use of non-traditional plant components in modern food technologies is a reserve in the creation of functional food [10]. New products must be safe, satisfy the need for essential nutrients, and also contain biologically active components that have a prophylactic effect on the human body.

The relevance of this research lies the development of canned food with increased biological value from beef with the plant complex "spirulina-flax".

Spirulina is a blue-green algae rich in high quality nutrients, especially protein $(65-72 \%)$ and B-carotene. Spirulina contains a unique biologically available amino acid complex and a rich composition of vitamins B, A, E and F, at the same time, vitamins C and $\mathrm{D}$ are practically absent. Flax is a unique plant component, the seeds of which are a source of complete protein, vitamins, fiber, and microelements. Due to its composition, flax seeds are a product that has a beneficial effect on the body as a whole.

The work aimed to develop a new product "Stewed meat" with biologically active complex of plant origin "spirulina-flax". According to the goal, the following tasks were solved:

- the study of the nutritional value of canned meat with different contents of the complex "spirulina-flax";

- study of vitamin and mineral composition of experimental samples of the new product;

- study of organoleptic and physico-chemical parameters of the new product;

- development of scientifically justified recipes and technology of a new product with a vegetable complex "spirulina-flax".

\section{Materials and methods}

Development of new canned products was carried out in the laboratories of the Federal State Budgetary Educational Institution of Higher Professional Education Oryol State Agrarian University named after N.V. Parakhin and "Oryolproduct" of Mtsensk district of Oryol region. Studies of the product were conducted in two to three replications. Statistical processing of the results of the research was carried out with the application package "Statistika 6.0". Calculations were carried out with the help of the "Microsoft Office 2010" package. The technological process at the enterprise was carried out per the technological instructions in compliance with the sanitary rules for the meat industry enterprises, Technical Regulations of the Customs Union 021/2011 "About safety of foodstuff", Technical Regulations of the Customs Union 034/2013 "About safety of meat and meat products" and regulatory legal acts in force on the territory of the Russian Federation.

Four samples of canned beef were produced under laboratory conditions. Three of them contained different amounts of complex "spirulina-flax". Sample № 1 contained $2 \%$ of complex "spirulina-flax" (1\% - spirulina, $1 \%$ - flaxseed meal). Sample № 2 contained $4 \%$ "spirulina-flax" complex (2\% - spirulina, $2 \%$ - flax seed meal). Sample № 3 contained 6\% "spirulina-flax" complex (3\% - spirulina, 3\% - flaxseed meal). Sample № 4 was a control and did not contain spirulina-flax complex. As a control, we took canned beef "Meat stew" following GOST 32125-2013. The amount of added plant components was determined based on recommendations for their nutritional use and the possibility of using these additives to form the functional value of new canned meat. Dry Spirulina platensis and flax seed flour were used in the studies. 
In the process of research, quantitative and qualitative indicators of the finished canned meat, protein fractions were studied, and the digestibility of proteins in the finished product was determined in vitro (by trypsin).

Recipe of experimental samples is given in Table 1.

Table 1. Recipe of canned food prototypes.

\begin{tabular}{|l|c|c|c|c|}
\hline \multirow{4}{*}{ Name of raw material } & \multicolumn{4}{|c|}{ Mass fraction of components, \% } \\
\cline { 2 - 5 } & $\begin{array}{c}\text { Sample №1, } \\
\mathbf{2 \%} \\
\text { "spirulina- } \\
\text { flax" complex }\end{array}$ & $\begin{array}{c}\text { Sample №2 } \\
\mathbf{4} \% \\
\text { "spirulina- } \\
\text { flax" complex }\end{array}$ & $\begin{array}{c}\text { Sample №3 } \\
\mathbf{6} \% \\
\text { "spirulina- } \\
\text { flax" complex }\end{array}$ & $\begin{array}{c}\text { Sample №4 } \\
\text { Beef stew first } \\
\text { grade GOST } \\
\mathbf{3 2 1 2 5 - 2 0 1 3}\end{array}$ \\
\hline $\begin{array}{l}\text { Ground beef with a mass } \\
\text { fraction of fat and connective } \\
\text { tissues not exceeding 14\% }\end{array}$ & 95.50 & 93.50 & 91.50 & 97.50 \\
\hline Fresh chopped onions & 1.33 & 1.33 & 1.33 & 1.33 \\
\hline Common salt & 1.14 & 1.14 & 1.14 & 1.14 \\
\hline Ground black pepper & 0.01 & 0.01 & 0.01 & 0.01 \\
\hline Laurel leaf & 0.02 & 0.02 & 0.02 & 0.02 \\
\hline Spirulina & $1 \%$ & $2 \%$ & $3 \%$ & - \\
\hline Flax seed flour & $1 \%$ & $2 \%$ & $3 \%$ & - \\
\hline
\end{tabular}

\section{Results and discussion}

An important indicator that determines the compliance of a product with its purpose is its organoleptic characteristics and biological value, which is defined as a combination of components and biopolymers of a food product, in the presence of which a person's needs for metabolic energy and plastic substances for the normal functioning of the body are satisfied $[1,3,8]$.

The organoleptic assessment of the obtained samples is presented in table 2 .

Table 2. Organoleptic characteristics of canned food prototypes.

\begin{tabular}{|l|c|c|c|c|}
\hline \multicolumn{1}{|c|}{ Name } & Appearance & Scent & Consistency & $\begin{array}{c}\text { Average score } \\
( \pm \mathbf{0 . 0 2})\end{array}$ \\
\hline Sample №1 & 5 & 4 & 5 & 4.67 \\
\hline Sample №2 & 5 & 5 & 4 & 4.67 \\
\hline Sample № 3 & 4 & 4 & 4 & 4.00 \\
\hline Sample № 4 & 5 & 5 & 5 & 5.0 \\
\hline
\end{tabular}

Table 2 shows that the highest score for organoleptic characteristics was received by canned food made from beef meat with a spirulina-flax complex in an amount of $2 \%, 4 \%$ and a control sample according to GOST.

Studies of the chemical composition of canned food prototypes are presented in Table 3. It was found that when $2 \%$ and $4 \%$ of the "spirulina-flax" complex is added to the recipe, the amount of protein, fat and calorie content slightly decreases relative to the control, carbohydrates appear due to the introduced plant raw materials. A further increase in the amount of the introduced plant complex leads to a noticeable decrease in the main parameters of the composition of canned food and significant differences from the hosted control sample. 
Table 3. Chemical composition of canned food test samples.

\begin{tabular}{|l|c|c|c|c|}
\hline \multirow{2}{*}{ Component name } & \multicolumn{4}{|c|}{ Mass fraction of components, \% } \\
\cline { 2 - 5 } & $\begin{array}{c}\text { Sample №1. } \\
\mathbf{2 \%} \\
\text { "spirulina- } \\
\text { flax" complex }\end{array}$ & $\begin{array}{c}\text { Sample №2. } \\
\mathbf{4 \%} \\
\text { "spirulina- } \\
\text { flax" complex }\end{array}$ & $\begin{array}{c}\text { Sample №3. } \\
\mathbf{6 \%} \\
\text { "spirulina- } \\
\text { flax" complex }\end{array}$ & $\begin{array}{c}\text { Sample №4 } \\
\text { Beef stew first } \\
\text { grade GOST } \\
\mathbf{3 2 1 2 5 - 2 0 1 3}\end{array}$ \\
\hline Protein & 14.7 & 14.6 & 14.5 & 15 \\
\hline Fat & 16.8 & 16.6 & 16.5 & 17 \\
\hline Carbohydrates & 0.2 & 0.4 & 0.6 & 0 \\
\hline Energy value: kcal & 213.00 & 219.00 & 225.00 & 213.00 \\
\hline Common salt & $1 \%$ & $1 \%$ & $1 \%$ & $1.0-1.5 \%$ \\
\hline
\end{tabular}

The vitamin and mineral composition of experimental canned food is presented in Table 4.

Table 4. Vitamin and mineral composition of the experimental canned food.

\begin{tabular}{|l|c|c|c|c|}
\hline \multirow{2}{*}{ Component name, mkg } & \multicolumn{4}{|c|}{ Mass fraction of components, \% } \\
\cline { 2 - 5 } & $\begin{array}{c}\text { Sample №1, } \\
\mathbf{2 \%} \\
\text { "spirulina- } \\
\text { flax" complex }\end{array}$ & $\begin{array}{c}\text { Sample №2, } \\
\mathbf{4 \%} \\
\text { "spirulina- } \\
\text { flax" complex }\end{array}$ & $\begin{array}{c}\text { Sample №3, } \\
\text { 6\% "spirulina- } \\
\text { flax" complex }\end{array}$ & $\begin{array}{c}\text { Sample №4, } \\
\text { Beef stew first } \\
\text { grade GOST } \\
\mathbf{3 2 1 2 5 - 2 0 1 3}\end{array}$ \\
\hline Vitamins: & 3.7 & 3.8 & 3.9 & 3.4 \\
\hline $\mathrm{E}$ & 0.17 & 0.19 & 0.20 & 0.17 \\
\hline $\mathrm{B} 1$ & 4.2 & 4.4 & 4.7 & 4.2 \\
\hline $\mathrm{PP}$ & \multicolumn{5}{|l|}{} \\
\hline $\mathrm{M}$ Mineral components: & 392 & 416 & 429 & 381 \\
\hline $\mathrm{Ca}$ & 29 & 34 & 39 & 26 \\
\hline $\mathrm{Mg}$ & 255 & 262 & 269 & 242 \\
\hline $\mathrm{P}$ & \multicolumn{5}{|l|}{} \\
\hline
\end{tabular}

Experimental canned products differed by the changed vitamin and mineral composition. So, in samples 1, 2, and 3, the contents of vitamin E, B1, and PP were higher than in the control sample. Vitamin E - by 8,11 and 14\%, vitamin B1 - by $0,11,28 \%$, vitamin $\mathrm{PP}-0,4,11 \%$, respectively. The amount of vitamins $\mathrm{PP}$ and $\mathrm{B}_{1}$ in sample №1 remained at the same level as in the control. The experimental canned samples 1, 2, and 3 had higher contents of $\mathrm{Ca}, \mathrm{Mg}, \mathrm{P}$ by the content of mineral components. Thus, calcium was higher by 2, 9, and 12\%; magnesium by 11,30 , and $50 \%$; phosphorus by 5.8 and $11 \%$ relative to the control. This indicates a higher biological value of the developed canned foods. The trypsin digestibility of the experimental canned samples is presented in Table 5.

Table 5. In vitro digestibility (by trypsin) of experimental canned meat.

\begin{tabular}{|l|c|}
\hline \multicolumn{1}{|c|}{ Name of the sample of canned food } & $\begin{array}{c}\text { In vitro digestibility (by } \\
\text { trypsin), \% }\end{array}$ \\
\hline Sample №1, 2\% "spirulina-flax" complex & $91 \pm 0.06$ \\
\hline Sample №2, 4\% "spirulina-flax" complex & $91 \pm 0.05$ \\
\hline Sample №3, 6\% "spirulina-flax" complex & $92 \pm 0.07$ \\
\hline Sample №4, Beef stew first grade (к) & $91 \pm 0.02$ \\
\hline
\end{tabular}

The results of in vitro (trypsin) digestibility studies of experimental canned food samples indicate insignificant changes associated with the introduction of spirulina-flax plant complex to the canned food recipe. All samples were distinguished by high digestibility at the level of $91-92 \%$. 


\section{Conclusions}

Additional vegetable raw materials can increase the biological value of canned food due to vitamins, minerals, and dietary fiber while maintaining the requirements of GOST. The added plant complex enriches the product with biologically valuable components of plant origin, with an insignificant increase in the energy value. Based on the data, it is possible to recommend enterprises to use the obtained composition for the production of canned food with an increased biological value. Also, based on these results, to develop new recipe compositions in the conditions of the enterprise.

\section{References}

1. A.V. Arkhipov, J. Bulletin of the Bryansk State Agricultural Academy. 1, 16 (2010)

2. V.M. Pozdnyakovsky, Text. for univer. 522 (2008)

3. V.M. Pozdnyakovsky, A. N. Austrievskikh, A. A. Vekovtsev, Kuzbassvuzizdat:ASTSH. 257 (2007)

4. A.N. Zakharov, M. V. Tikhonov, M. D. Askhabova, S. M. Plachenko, J. All about meat. 4, 20 (2014)

5. V.V. Pryanishnikov, A.V. Iltyakov, G. I. Kasyanov, Ekonomist. 164 (2011)

6. A.V. Mamaev, N. D. Rodina, E. Yu. Sergeeva, K. A. Leshchukov, T. N. Suchkova, S. S. Tsikin, J. Biology in agriculture. 4, 14 (2016)

7. L.S. Kolesnik, T. N. Suchkova, A.V. Mamaev, J. West-Siberian Scientific Center. 2, 404 (2016)

8. A.P. Simonenkova, M.V. Yarkina, A.O. Solovyova, A.V. Mamaev, O.N. Luneva, International Conference "Agro-SMART - Smart solutions for agriculture" 2018 will be held at the Northern Trans-Ural State Agricultural University, Tyumen, 652 (2018)

9. A.P. Simonenkova, A.V. Mamaev, V.N. Masalov and others, International Conference on Production and Processing of Agricultural Raw Materials, Voronezh, V.640, 26 (2020)

10. N.A. Berezina, A.V. Artemov, I.A. Nikitin, V.A. Kozlova. N.A. Makarova, International Conference on Production and Processing of Agricultural Raw Materials, Voronezh, V.640, 29 (2020)

11. N.A. Berezina, A.V. Artemov, I.A. Nikitin, A.A. Budnik, International Journal of Advanced Computer Science and Applications. 10 (5), 137-143 (2019)

12. V.N. Ivanova, I.A. Nikitin, N.A. Zhuchenko, M.A. Nikitina, Y.I. Sidorenko, V.I. Karpov, I.A. Zavalishin, International Journal of Advanced Computer Science and Applications. 10 (2), 45-50 (2019) 